\title{
A reason for sophisticated investors not to seize arbitrage opportunities in markets without frictions
}

Citation for published version (APA):

Rohde, K. I. M. (2005). A reason for sophisticated investors not to seize arbitrage opportunities in markets without frictions. METEOR, Maastricht University School of Business and Economics. METEOR Research Memorandum No. 054 https://doi.org/10.26481/umamet.2005054

Document status and date:

Published: 01/01/2005

DOI:

10.26481/umamet.2005054

Document Version:

Publisher's PDF, also known as Version of record

\section{Please check the document version of this publication:}

- A submitted manuscript is the version of the article upon submission and before peer-review. There can be important differences between the submitted version and the official published version of record.

People interested in the research are advised to contact the author for the final version of the publication, or visit the DOI to the publisher's website.

- The final author version and the galley proof are versions of the publication after peer review.

- The final published version features the final layout of the paper including the volume, issue and page numbers.

Link to publication

\footnotetext{
General rights rights.

- You may freely distribute the URL identifying the publication in the public portal. please follow below link for the End User Agreement:

www.umlib.nl/taverne-license

Take down policy

If you believe that this document breaches copyright please contact us at:

repository@maastrichtuniversity.nl

providing details and we will investigate your claim.
}

Copyright and moral rights for the publications made accessible in the public portal are retained by the authors and/or other copyright owners and it is a condition of accessing publications that users recognise and abide by the legal requirements associated with these

- Users may download and print one copy of any publication from the public portal for the purpose of private study or research.

- You may not further distribute the material or use it for any profit-making activity or commercial gain

If the publication is distributed under the terms of Article $25 \mathrm{fa}$ of the Dutch Copyright Act, indicated by the "Taverne" license above, 


\title{
A Reason for Sophisticated Investors not to seize Arbitrage Opportunities in Markets without Frictions
}

\author{
Kirsten I.M. Rohde*
}

December 13, 2005

Arbitrage opportunities exist when it is possible to generate a nonnegative income stream without incurring any costs. This is, for instance, the case when it is possible to buy a portfolio of assets that costs nothing today and that will yield a positive payoff in the future. It is a widespread belief that, as long as there are no market frictions, arbitrage opportunities cannot exist. The reason is that as long as they do exist, the demand for the portfolio of assets mentioned before will be very large, exceeding supply, which will drive the price of the portfolio up until arbitrage is no longer possible.

Here we will show that this belief can be incorrect when preferences change over time. Since Strotz's (1955-1956) discussion of behavior when preferences change over time, there has been an increasing interest in economic models that do account for changing preferences, including Akerlof (2002), Angeletos et al. (2001), Barro (1999), Frederick et al. (2002), Gul and Pesendorfer (2001), Harris and Laibson (2001), Herings and Rohde (2006), Krusell and Smith (2003), Krusell et al. (2002), Laibson (1997), Loewenstein and Prelec (1992), Luttmer and Mariotti (2003), O’Donoghue and Rabin (1999a, 1999b), Phelps and Pollak (1968), Rubinstein (2003), and Thaler and Benartzi (2004).

When preferences change over time, several types of behavior can be distinguished.

${ }^{*}$ Department of Economics, Maastricht University, P.O. Box 616, 6200 MD Maastricht, The Netherlands. E-mail: K.Rohde@algec.unimaas.nl 
Individuals may either recognize the fact that their preferences will change in the future, or believe that their preferences will not change. Individuals who believe that their preferences will not change over time are called naïve (Pollak, 1968). Individuals who do recognize that their preferences may change, either pre-commit themselves or only make plans that they expect to adhere to in the future. Pre-commitment may only be possible when there are pre-commitment devices. If there are no pre-commitment devices it can be hard for the individual to stick to the plans he made in the past. Then sophisticated individuals will only make plans that they expect to adhere to in the future. These sophisticated individuals first try to predict their future behavior for every given possible current behavior. They then choose the current behavior that, together with the reaction on this behavior in the future, is the best from the perspective of current preferences. In predicting their future behavior individuals may predict their future preferences either correctly (Pollak, 1968) or incorrectly (Loewenstein, O'Donoghue, and Rabin, 2003). The former will be called fully sophisticated, and the latter partly sophisticated.

Crucial in the behavior of a sophisticated individual is that, by choosing current behavior, he will try to influence future behavior if that future behavior depends on current behavior. Akerlof (1991), Benhabib and Bisin (2005), DellaVigna and Malmendier (2004), Schelling (1984), Thaler and Shefrin (1981) give evidence and many examples of individuals trying to influence their future behavior by choosing the appropriate current behavior. Consider an addicted smoker deciding to try to quit smoking. If he is wise, he will completely abstain from smoking right from the beginning. Suppose that he would first restrict himself to smoking only one cigarette a day. Then, after smoking that one cigarette, he will be tempted even stronger to smoke a second cigarette and he might indeed give in to that temptation, ending up smoking more than one cigarette per day. If this smoker would be naïve, he would not foresee this increased temptation after smoking the first cigarette, and would indeed smoke the one cigarette, ending up smoking more than one cigarette after all. If he would be sophisticated, he would foresee this temptation, and thus, know that he would never stick to smoking only one cigarette. Knowing that his choice is restricted to either not smoking at all or smoking more than one cigarette, he may choose not to smoke 
at all.

This note gives an example of an individual investor who does not seize an arbitrage opportunity, only because he wants to influence future behavior. In the example, which is borrowed from Liebhafsky (1969), there is the possibility to buy an asset at zero costs today, which will yield a positive income tomorrow. Tomorrow, two goods can be consumed, one of which is an inferior good from the perspective of tomorrow. From the perspective of today, however, that good is not inferior. We can think of 'today' being the first half of our life and 'tomorrow' being the second half. The normal good is a luxurious and not so healthy basket of goods. The inferior good is a less luxurious and more healthy basket of goods. Suppose that we expect that as our income rises we will tend to purchase more of the luxurious basket and less of the healthy one. From the perspective of the first half of our life we wish we would keep buying the healthy basket and not switch to the luxurious one in the future. One way to make sure that we keep buying the healthy basket is to refrain our income from rising a lot.

The example not only shows the possibility for arbitrage opportunities to exist in equilibrium in rational markets, but is also relevant for optimal contract design. Consider a manager whose wage consists of an amount that depends on the profits the company makes. It is commonly believed that such a wage scheme will give the manager an incentive to maximize profits. Our example, however, shows that this wage scheme might also give the manager an incentive not to maximize profits, since he might not want to increase his future income indefinitely. This is an overlooked, though important observation that should be kept in mind when designing compensation schemes. For sophisticated decision-makers with changing preferences, increasing future income may not necessarily increase current utility. As an alternative to trying to give a manager the incentive to maximize profits by increasing the manager's income as profits increase, it might be better to give the manager that incentive by giving him more of a non-tradeable, but desired, good as profits increase. In that way, an increase in profits will not change the consumption bundle that the manager will buy tomorrow too much, so that from the perspective of today, he will prefer the new consumption bundle tomorrow. This will give him an incentive to maximize profits. 
We assume that there are two subsequent periods. These two periods can be interpreted freely, but for ease of exposition, we label them 'today' and 'tomorrow'. There is no uncertainty. Today investors buy portfolios of assets that will pay off tomorrow. Tomorrow investors consume goods. There are two goods that can be consumed tomorrow: good 1 and good 2. The expenditures are limited by income, which is determined by two components. The investor has an initial endowment of every good tomorrow. The value of endowments tomorrow and the payoffs tomorrow of the assets bought today together constitute income tomorrow. There are no market frictions, i.e. investors are allowed to go short or long in assets without bounds and tomorrow there are complete spot markets.

Consider an investor with endowments $\omega=\left(\omega_{1}, \omega_{2}\right)=(1 / 2,3 / 2)$, i.e. $1 / 2$ units of good 1 and 3/2 units of good 2. The prices of these two goods are expected to be equal to 1 tomorrow, and will indeed be equal to 1 tomorrow. There is one asset, that can be bought today at zero costs. This asset will pay off 1 unit of money tomorrow. We will argue later that such an asset can indeed exist in the market. Thus, the income of the investor tomorrow will be equal to

$$
I=\omega_{1}+\omega_{2}+\theta
$$

where $\theta$ is the amount of assets bought today.

Today the preferences of the investor over consumption tomorrow are represented by the following utility function:

$$
U^{0}\left(x_{1}, x_{2}\right)=\min \left\{3 x_{1}, x_{2}\right\}
$$

where $x_{1}$ and $x_{2}$ are the consumption of good 1 and good 2, respectively. The investor believes that his preferences over consumption will be different tomorrow. He believes that his preferences tomorrow will be represented by

$$
U^{1}\left(x_{1}, x_{2}\right)=\frac{3}{4} \ln x_{1}+\frac{x_{2}^{2}}{2} .
$$

It can be shown that with the latter preferences consumption tomorrow will depend on 
income $I$ as follows: either

$$
\begin{aligned}
& x_{1}^{*}=\frac{1}{2}\left(I-\sqrt{I^{2}-3}\right) \text { and } \\
& x_{2}^{*}=\frac{1}{2}\left(I+\sqrt{I^{2}-3}\right)
\end{aligned}
$$

or $x_{1}^{*}=I$ and $x_{2}^{*}=0$. Today the sophisticated investor believes that his consumption will be like this tomorrow. Thus, he believes that his choice is restricted by (1) and (2). The only way in which he can influence tomorrow's consumption, is by influencing future income, through the sale or purchase of assets today.

Suppose that the investor decides not to invest in the costless asset, i.e. $\theta=0$. Then his income tomorrow will be equal to $I=\omega_{1}+\omega_{2}=1 / 2+3 / 2=2$. Then it follows that $x_{1}^{*}=1 / 2$ and $x_{2}^{*}=3 / 2$. Thus, he would keep his endowments.

Consider what would happen if he would decide to buy the asset. The curve in Fig. 1 shows tomorrow's demanded consumption bundles for various income levels if it does not hold that $x_{1}^{*}=I$. The dashed curve is an indifference curve from the perspective of today, that goes through $\omega$. From the perspective of today only bundles to the north-east of $\omega$ would be weakly preferred by our investor. However, by changing income, no bundles to the north-east of $\omega$ can be reached, given demand tomorrow. Thus, the investor will not buy the asset.

Note that the preferences of the investor are increasing in the consumption of the goods. Thus, tomorrow the investor would always wish he had more income. Also, if today he would be able to perfectly pre-commit himself, he would want to buy the asset in order to increase tomorrow's income. A perfect pre-commitment device would allow the investor to specify today how he would like to spend his income tomorrow and would not allow him to choose to spend his income differently tomorrow. Then the sophisticated investor would not be constrained by his behavior tomorrow and would want to increase his future income.

From the figure, we can see that there can be investors who do want to either increase or decrease their future income by a limited amount. Consider a second investor that has the same preferences as our first investor, but less income from endowments in the second 


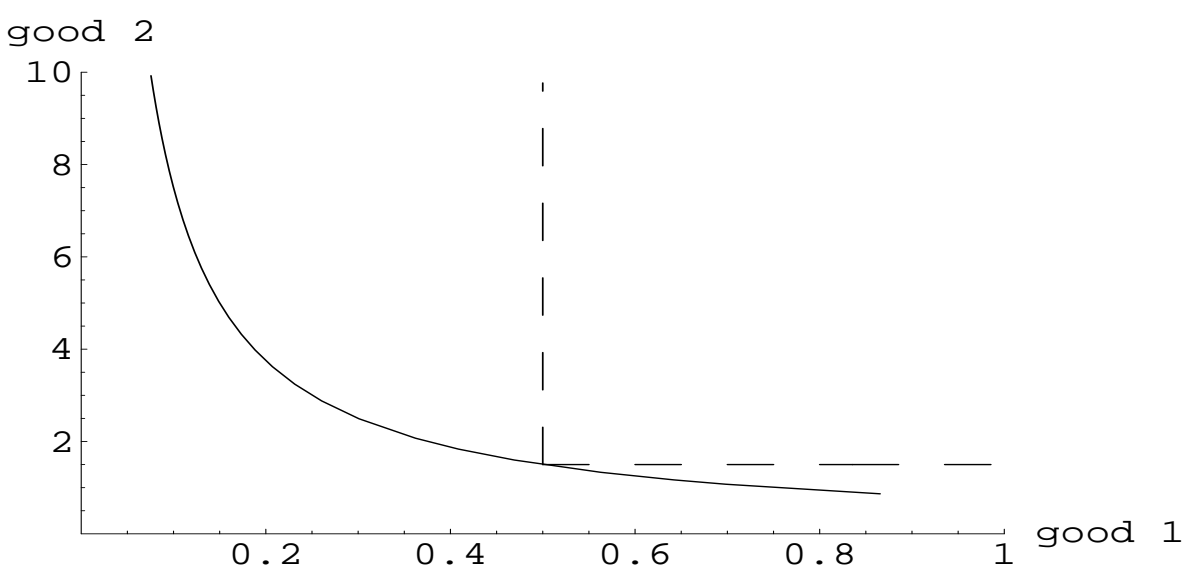

Figure 1: Tomorrow's consumption

period. This investor wants to increase his income in the second period, until he can afford the consumption bundle $\omega$. Similarly, a third investor that has a higher income from endowments than our first investor, wants to decrease his income, until he will choose the consumption bundle $\omega$ tomorrow. Thus, the second investor will buy the asset, whereas the third investor will sell the asset. The endowments of the second and third investor can be chosen in such a way that demand and supply of the asset are exactly equal when the price of the asset is equal to zero. Thus, the second and third investor will trade the asset. This shows that in equilibrium there can indeed exist an asset in the market that (1) costs nothing, (2) yields a positive payoff in a future period, and (3) is traded.

From this example we see that the existence of arbitrage opportunities in the market may not only be due to market frictions like, for instance, transaction costs, asymmetric information and restrictions to borrow money. Though it is a common belief that everybody would want to increase future income at no costs, this may not always be rational.

\section{References}

Akerlof, G.A. (2002), "Behavioral Macroeconomics and Macroeconomic Behavior," Amer- 
ican Economic Review, 92, 411-433.

Akerlof, G.A. (1991), "Procrastination and Obedience," American Economic Review, 81, $1-19$.

Angeletos, G.M., D. Laibson, A. Repetto, J. Tobacman, and S. Weinberg (2001), "The Hyperbolic Consumption Model: Calibration, Simulation, and Empirical Evaluation," Journal of Economic Perspectives, 15, 47-68.

Barro, R.J. (1999), "Ramsey meets Laibson in the Neoclassical Growth Model," Quarterly Journal of Economics, 114, 1125-1152.

Benhabib, J., and A. Bisin (2005), "Modeling Internal Commitment Mechanisms and Selfcontrol: A Neuroeconomics Approach to Consumptionsaving Decisions," Games and Economic Behavior, 52, 460-492.

DellaVigna, S., and U. Malmendier (2004), "Contract Design and Self-Control: Theory and Evidence," Quarterly Journal of Economics, 119, 353-402.

Frederick, S., G. Loewenstein, and T. O'Donoghue (2002), "Time Discounting and Time Preference: a Critical Review," Journal of Economic Literature, 40, 351-401.

Gul, F., and W. Pesendorfer (2001), "Temptation and Self-control," Econometrica, 69, 1403-1435.

Harris, C., and D. Laibson (2001), "Dynamic Choices of Hyperbolic Consumers," Econometrica, 69, 935-957.

Herings, P.J.J., and K.I.M. Rohde (2006), "Time-inconsistent preferences in a general equilibrium model," Economic Theory, forthcoming.

Krusell, P., and A. Smith (2003), "Consumption-savings Decisions with Quasi-geometric Discounting," Econometrica, 71, 365-375.

Krusell, P., B. Kuruşçu, and A.A. Smith (2002), "Equilibrium Welfare and Government Policy with Quasi-geometric Discounting," Journal of Economic Theory, 105, 42-72.

Laibson, D. (1997), "Golden Eggs and Hyperbolic Discounting," Quarterly Journal of Economics, 112, 443-477.

Liebhafsky, H. H. (1969), "New Thoughts about Inferior Goods," American Economic Review, 59, 931-934. 
Loewenstein, G., O’Donoghue, T., and Rabin, M. (2003), "Projection Bias in Predicting Future Utility," Quarterly Journal of Economics, 118, 1209-1248.

Loewenstein, G., and D. Prelec (1992), “Anomalies in Intertemporal Choice: Evidence and an Interpretation, Quarterly Journal of Economics, 107, 573-597.

Luttmer, E.G.J., and T. Mariotti (2003), "Subjective Discounting in an Exchange Economy," Journal of Political Economy, 111, 1-30.

O’Donoghue, T., and M. Rabin (1999a), "Doing it Now or Later," American Economic Review, 89, 103-124.

O’Donoghue,T., and M. Rabin (1999b), "Incentives for Procrastinators," Quarterly Journal of Economics, 114, 769-816.

Phelps, E.S., and Pollak, R.A. (1968), "On Second-Best National Saving and GameEquilibrium Growth," Review of Economic Studies, 35, 185-199.

Pollak, R.A. (1968), "Consistent Planning," Review of Economic Studies, 35, 201-208.

Rubinstein, A. (2003), “'Economics and Psychology'? The Case of Hyperbolic Discounting," International Economic Review, 44, 1207-1216.

Schelling, T.C. (1984), "Self-Command in Practice, in Policy, and in a Theory of Rational Choice," American Economic Review, 74, 1-11.

Strotz, R.H. (1955-1956), "Myopia and Inconsistency in Dynamic Utility Maximization," Review of Economic Studies, 23, 165-180.

Thaler, R.H., and S. Benartzi (2004), "Save More tomorrow: Using Behavioral Economics to Increase Employee Saving," Journal of Political Economy, 112, 164-187.

Thaler, R.H., and H.M. Shefrin (1981), "An Economic Theory of Self-Control," Journal of Political Economy, 89, 392-406. 